\title{
Corrosion Protection of SiC-Based Ceramics with CVDMullite Coatings
}

\section{RECEIVED \\ JUL 10 PQ97 \\ OSTI}

May 1, 1997

\author{
Report Prepared by \\ Vinod Sarin and Michael Auger \\ Boston University \\ Manufacturing Engineering \\ 15 St. Mary's Street \\ Boston MA 02215 \\ under \\ ORLN/Sub/94-SS110/02 \\ for \\ OAK RIDGE NATIONAL LABORATORY \\ Oak Ridge, Tennessee 37831 \\ Managed by \\ LOCKHEED MARTIN ENERGY RESEARCH CORP. \\ for the \\ U.S. DEPARTMENT OF ENERGY \\ under contract DE-AC05-96OR22464
}

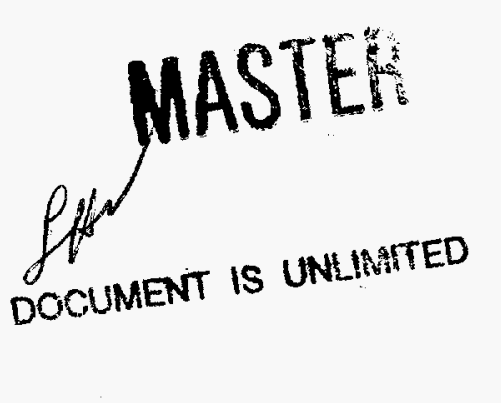




\section{DISCLAIMER}

Portions of this document may be illegible electronic image products. Images are produced from the best available original document. 


\title{
Corrosion Protection of SiC-Based Ceramics with CVDMullite Coatings
}

\author{
May 1, 1997 \\ Report Prepared by \\ Vinod Sarin and Michael Auger \\ Boston University \\ Manufacturing Engineering \\ 15 St. Mary's Street \\ Boston MA 02215 \\ under \\ ORLN/Sub/94-SS110/02 \\ for \\ OAK RIDGE NATIONAL LABORATORY \\ Oak Ridge, Tennessee 37831 \\ Managed by \\ LOCKHEED MARTIN ENERGY RESEARCH CORP. \\ for the \\ U.S. DEPARTMENT OF ENERGY \\ under contract DE-AC05-96OR22464
}




\author{
Abstract \\ Introduction
}

Thermodynamic Analysis

Kinetic Considerations

Experimental Methods

Results and Discussion

Effect of Input Gas Stoichiometry

The Effects of Depletion

The Effects of Post-Deposition Thermal Treatment

Corrosive Environment Studies

Oxidation Environment

$\mathrm{Na}_{2} \mathrm{SO}_{4}, \mathrm{O}_{2}$ Environment

Coal Slag Environment

Conclusions

Acknowledgments

Distribution Lists 
Research sponsored by the U.S. Department of Energy, Fossil Energy Advanced Research and Technology Development Materials Program, DOE/FE AA 151010 0, Work Breakdown Structure Element BU-2

\begin{abstract}
For the first time, adherent crystalline mullite coatings have been chemically vapor deposited onto SiC substrates to enhance its corrosion/oxidation resistance. Thermodynamic and kinetic considerations have been utilized to produce mullite coatings with a variety of growth rates, compositions, and morphologies. The flexibility of processing can be exploited to produce coated ceramics with properties tailored to specific applications and varied corrosive environments. These corrosive environments include thermal, $\mathrm{Na}_{2} \mathrm{SO}_{4}, \mathrm{O}_{2}$, and coal slag.
\end{abstract}


1

Research sponsored by the U.S. Department of Energy, Fossil Energy Advanced Research and Technology Development Materials Program, DOE/FE AA 151010 0, Work Breakdown Structure Element BU-2

Abstract (Unsent 1 sit paragraph of Introduction)

For the first time, adherent crystalline mullite coatings have been chemically vapor deposited onto $\mathrm{SiC}$ substrates to enhance its corrosion/oxidation resistance. Thermodynamic and kinetic considerations have been utilized to produce mullite coatings with a variety of growth rates, compositions, and morphologies. The flexibility of processing can be exploited to produce coated ceramics with properties tailored to specific applications and varied corrosive environments. These corrosive environments include thermal, $\mathrm{Na}_{2} \mathrm{SO}_{4}, \mathrm{O}_{2}$, and coal slag.

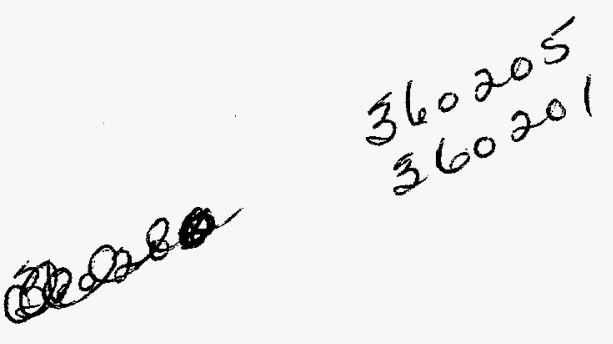




\section{INTRODUCTION}

Silicon carbide ceramics are the leading candidate materials for use as heat exchangers in advanced combined cycle power plants because of their unique combination of high temperature strength, high thermal conductivity, excellent thermal shock resistance, and good high temperature stability and oxidation resistance. Ceramic coatings are being considered for diesel engine cylinder liners, piston caps, valve faces and seats, piston rings, and for turbine components such as combustors, blades, stators, seals, and bearings [1]. Under such conditions ceramics are better suited to high temperature environments than metals.

$\mathrm{Si}_{3} \mathrm{~N}_{4}$ and $\mathrm{SiC}$ are limited by their susceptibility to specific high temperature corrosive environments, including fossil fuels. These environments include but are not limited to hot gas streams containing trace amounts and combinations of impurities such as $\mathrm{SO}_{\mathrm{x}} \mathrm{NaCl}$, and $\mathrm{O}_{2}[2]$. Combined with the inherent liability of monolithic ceramics to contact stress failure, this corrosion resistance limitation has lead to the development of protective coatings. Innumerable coatings have been developed throughout the last seven decades yet none has met the complex internal requirements of high temperature engines [3].

Mullite has been targeted as a potential coating material for silicon based ceramics such as $\mathrm{Si}_{3} \mathrm{~N}_{4}$ and $\mathrm{SiC}$. In addition to traditional refractory applications, mullite has received considerable attention as a high temperature material because of its unique ability to retain its strength, resist creep, and avoid thermal shock failure at elevated temperatures $[4,5,6,7] . \quad$ At atmospheric pressure, mullite is the only stable crystalline compound in the $\mathrm{Al}_{2} \mathrm{O}_{3}-\mathrm{SiO}_{2}$ system. Stoichiometric mullite is quoted as $3 \mathrm{Al}_{2} \mathrm{O}_{3} \bullet 2 \mathrm{SiO}_{2}$ yet exists between 57 and 74 mole\% $\mathrm{Al}_{2} \mathrm{O}_{3}$. The crystal 
structure of mullite is a modified defect structure of sillimanite $\left(\mathrm{Al}_{2} \mathrm{O}_{3} \bullet \mathrm{SiO}_{2}\right)$ in which the mullite stoichiometry is achieved by substituting $\mathrm{Si}^{4+}$ ions with $\mathrm{Al}^{3+}$ ions in the tetrahedral sites and forming an oxygen vacancy [8,9]. The well accepted defect structure is expressed as $\mathrm{Al}^{\mathrm{VI}}{ }_{2}\left(\mathrm{Al}^{\mathrm{IV}}{ }_{2+2 \mathrm{X}} \mathrm{Si}_{2-2 \mathrm{x}}\right) \mathrm{O}_{10-\mathrm{x}}$ where $\mathrm{x}$ denotes the amount of missing oxygen and $\mathrm{VI}$ and IV denote sixfold and four-fold coordination. Stoichiometric mullite is orthorhombic and theoretically fits between sillimanite $(x=0)$ and alumina $(x=1)[10]$. This full solid solution range has not been achieved in practice and mullite rarely exists beyond $76 \mathrm{~mol} \%$ alumina with conventional processing. Solid solubility depends on the formation process and the cooling rate with extreme $\mathrm{Al}_{2} \mathrm{O}_{3}$ concentrations resulting from temperatures in excess of $2000^{\circ} \mathrm{C}$ and rapid cooling rates.

Previous attempts to grow mullite coatings by various processing methods have met with limited success [11]. Most commonly reported techniques require a post deposition heat treatment to convert the amorphous alumina-silicate into crystalline mullite $[12,13]$. Deposition of plasma sprayed mullite coatings have been reported; however, inherent porosity in the coatings resulted in migration of corrodants through the coating after a few hundred hours [14]. To overcome these deficiencies, the direct formation of chemically vapor deposited (CVD) mullite coatings has been investigated. The CVD process results in dense adherent coatings with the ability to control microstructural and morphological properties. 


\section{THERMODYNAMIC ANALYSIS}

Equilibrium thermodynamics was performed on the $\mathrm{AlCl}_{3}-\mathrm{SiCl}_{4}-\mathrm{CO}_{2}-\mathrm{H}_{2}$ system to establish equilibrium reaction products at various operating conditions. This analysis has been detailed in previous publications $[15,16]$. and were used to create CVD phase diagrams that help establish guidelines for input conditions for producing mullite and other compounds at equilibrium. The overall equilibrium reaction yielding mullite from the reactant gases utilized in the CVD process is theorized to be the following:

$$
6 \mathrm{AlCl}_{3}+2 \mathrm{SiCl}_{4}+13 \mathrm{CO}_{2}+13 \mathrm{H}_{2} \rightarrow 3 \mathrm{Al}_{2} \mathrm{O}_{3} \cdot 2 \mathrm{SiO}_{2}+13 \mathrm{CO}+26 \mathrm{HCl}
$$

Thermodynamic analysis was performed using a wide range of conditions including temperatures between 800 and $1200^{\circ} \mathrm{C}$ and system pressures between 2 and 150 torr. The results of the previous analysis determined that low concentrations of chlorides need to be used to obtain high deposition efficiency and carbon free deposits.

\section{KINETIC CONSIDERATIONS}

A comprehensive thermodynamic analysis is necessary but not sufficient for understanding the CVD process parameters required to grow mullite coatings. Analyzing the kinetic steps, in particular the rate limiting step, involved in the coating deposition is also essential. Current studies focus on collecting experimental data concerning the kinetics of CVD mullite formation using $\mathrm{AlCl}_{3}, \mathrm{SiCl}_{4}, \mathrm{H}_{2}$, and $\mathrm{CO}_{2}$. Kinetic considerations are being taken from the formation of the 
well established oxide coatings $\mathrm{Al}_{2} \mathrm{O}_{3}$ and $\mathrm{SiO}_{2}$ using chloride reactants. The formation of $\mathrm{Al}_{2} \mathrm{O}_{3}$ proceeds via this hydrolysis reaction:

$$
\begin{aligned}
& \mathrm{CO}_{2}(\mathrm{~g})+\mathrm{H}_{2}(\mathrm{~g}) \rightarrow \mathrm{CO}(\mathrm{g})+\mathrm{H}_{2} \mathrm{O}(\mathrm{g}) \\
& 2 \mathrm{AlCl}_{3}(\mathrm{~g})+3 \mathrm{H}_{2} \mathrm{O}(\mathrm{g}) \rightarrow \mathrm{Al}_{2} \mathrm{O}_{3}(\mathrm{~g})+6 \mathrm{HCl}(\mathrm{g})
\end{aligned}
$$

It has been shown that the reaction rate of $\mathrm{AlCl}_{3}$ with $\mathrm{O}_{2}$ is extremely slow while $\mathrm{AlCl}_{3}$ reacts vigorously with $\mathrm{H}_{2} \mathrm{O} . \quad \mathrm{AlCl}_{3}, \mathrm{H}_{2}$, and $\mathrm{CO}_{2}$ exhibit a moderate reaction rate and avoid homogenous nucleation [17]. The reaction proceeds via reaction (2) where reaction (2.1)is labeled the water-gas shift reaction. It has also been stated that $\mathrm{SiO}_{2}$ is formed via the hydrolysis mechanism at $1000^{\circ} \mathrm{C}$, yet it is unclear whether $\mathrm{SiO} 2$ can easily form via another mechanism [18].

Experimentally it has been found that the rate is proportional to the concentration of both reactants (assuming the reaction is irreversible). Hence the rate equation for $\mathrm{H}_{2} \mathrm{O}$ production is

$$
R_{\mathrm{H} 2 \mathrm{O}}=\mathrm{k}\left[\mathrm{CO}_{2}\right]^{\mathrm{n}}\left[\mathrm{H}_{2}\right]^{\mathrm{m}}
$$

In this equation, $k$ is called the rate constant for this reaction. It is independent of concentration yet will vary with temperature according to the Arrhenius relation. The factors $n$ and $m$ refer to the rates of the equation and are not necessarily equal to the stoichiometry of the formation equation. For instance if $n=1$ the reaction is considered first order with respect to carbon dioxide. 
The water-gas shift reaction has been extensively studied due to its applicability to metal oxide reactions [19]. Analysis of the reaction over the temperature range 400 to $1050^{\circ} \mathrm{C}$ suggest separate low temperature and high temperature reaction paths. The low temperature reaction path is dominant at temperatures below $800^{\circ} \mathrm{C}$ and is extremely sensitive to trace impurities such as oxygen. The high temperature reaction is homogenous and dominant at temperatures in excess of $800^{\circ} \mathrm{C}$. The respective low and high temperature mechanisms (determined by measuring $\mathrm{CO}$ concentration) are as follows:

$$
\begin{aligned}
& \text { Low Temperature: } d \mathrm{C}_{\mathrm{co}} / d \mathrm{t}=7.6 \times 10^{4} \operatorname{Exp}\left(\frac{-39,200}{R T} *\right)\left[\mathrm{H}_{2}\right]^{1 / 3}\left[\mathrm{CO}_{2}\right] \\
& \text { High Temperature: } d \mathrm{C}_{\mathrm{co}} / d \mathrm{t}=1.2 \times 10^{13} \operatorname{Exp}\left(\frac{-78,000}{R T} *\right)\left[\mathrm{H}_{2}\right]^{1 / 2}\left[\mathrm{CO}_{2}\right] \\
& \text { *activation energy is stated in cal } / \mathrm{mole}
\end{aligned}
$$

The activation energy of $\mathrm{SiO}_{2}$ and $\mathrm{Al}_{2} \mathrm{O}_{3}$ on $\mathrm{Si}$ substrates varies according to experimental conditions. Two similar studies performed in cold-walled CVD reactors state an $\mathrm{SiO}_{2}$ activation energy of $82 \mathrm{kcal} / \mathrm{mol}$ [20]. and an $\mathrm{Al}_{2} \mathrm{O}_{3}$ activation energy of $34.8 \mathrm{kcal} / \mathrm{mol}$ [21]. These separate studies agree with numerous experimental observations in which $\mathrm{Al}_{2} \mathrm{O}_{3}$ deposition is particularly sensitive to trace impurities in the gas mixture resulting in homogenous (powdery) nucleation [22]. These previous kinetic studies have been used as guides for CVD mullite yet may not be used directly as the kinetics of the mixed chloride reaction will vary from the kinetics of the separate systems. 


\section{EXPERIMENTAL METHODS}

A CVD reactor consisting of a vertically hot-walled reactor with a resistively heated threezoned furnace was used for the experiments. Polished bars of $3 \times 4 \times 20 \mathrm{~mm}$ Hexaloy SiC (Carborundum Company, Niagara Falls, NY) were used as substrates. $\mathrm{AlCl}_{3}$ was formed in situ by flowing $\mathrm{Cl}_{2}$ with $\mathrm{Ar}$ as a carrier and dilutant through heated $\mathrm{Al}$ chips. $\mathrm{SiCl}_{4}$ vapor was introduced by evaporating the liquid at room temperature. $\mathrm{CO}_{2}$ and $\mathrm{H}_{2}$ were mixed with the chlorides prior to entering the deposition reactor. Excess $\mathrm{H}_{2}$ was present to ensure complete reduction of the metal chlorides to form $\mathrm{HCl}$ before exiting the reactor. The deposition technique is detailed in previous literature [23]. All depositions reported in this study were performed at $950^{\circ} \mathrm{C}$ and a total pressure of 75 torr. All coatings were characterized through x-ray diffraction (XRD) and scanning electron microscopy (SEM). Selected coatings were characterized with electron diffraction, transmission electron microscopy (TEM), and scanning transmission electron microscopy (STEM).

\section{RESULTS AND DISCUSSION}

Effect of Input Gas Stoichiometry

The effect of the input Al:Si ratio on the resultant mullite coating was investigated. The ratio of $\mathrm{Al}$ :Si was varied from pure $\mathrm{SiO}_{2}$ to pure $\mathrm{Al}_{2} \mathrm{O}_{3}$ with composite coatings varying between 1:1 to 4:1. Experimentally there are numerous methods to achieve the desired input Al:Si molar ratios. The two methods explored in this study are 1) varying the total partial pressure of metallic 
chlorides $\left(P_{M C l x}\right)$ by altering the flow rate of $\mathrm{AlCl}_{3}$ and holding the flow rate of $\mathrm{SiCl}_{4}$ constant and 2) holding $P_{M C l x}$ constant and varying both $\mathrm{AlCl}_{3}$ and $\mathrm{SiCl}_{4}$ to achieve the desired ratio.

The effect of varying the Al:Si ratio through varying $P_{M C l x}$ is shown in Figure 1. An initial increase in growth rate is seen as $\mathrm{AlCl}_{3}$ is introduced at an $\mathrm{Al}$ :Si ratio of $1: 1$ and $P_{M C l x}$ of 0.33 torr The coatings produced at a 1:1 ratio and $P_{M C l x}$ of 0.33 torr were not usually mullite when examined through XRD and exhibited a high degree of non-uniformity. TEM analysis reveled that these coatings were a nano-crystalline mixture of $\gamma-\mathrm{Al}_{2} \mathrm{O}_{3}$ and amorphous $\mathrm{SiO}_{2}$. This nanocrystalline layer was evident in all samples tested at all input ratios. Details of similar structural analysis may be found in a previous study [24]. The growth rate of the coating continues to decrease as the $\mathrm{AlCl}_{3}$ flow rate is increased to an $\mathrm{Al}$ :Si ratio of $4: 1$ and $P_{M C l x}$ of 0.93 torr. The degree of homogenous nucleation (powder formation) and non-uniformity in the coating continued to increase as the Al:Si ratio increased. The surface morphology of the coating becomes more faceted as the input $\mathrm{Al}: \mathrm{Si}$ ratio increases. Previous studies of $\mathrm{CVD}$ mullite coatings have shown that increased $\mathrm{Al}$ content increases the faceted nature of the coating [17]. Mullite coatings grown with an input $\mathrm{Al}$ :Si ratio of 2:1 were uniform, fine grained, and highly faceted with a growth rate of $3 \mu \mathrm{m} / \mathrm{hr}$. The growth rate for $\mathrm{Al}_{2} \mathrm{O}_{3}$ stated in Figure 1 is an average value taken from several literature sources under similar conditions. Attempts to deposit $\mathrm{Al}_{2} \mathrm{O}_{3}$ using mullite processing conditions resulted in significant homogenous nucleation. Pure $\mathrm{SiO}_{2}$ coatings under these conditions were found to be amorphous.

The effect of varying the $\mathrm{Al}: \mathrm{Si}$ ratio by increasing $P_{M C l x}$ on the initial nano-crystalline region is shown in Figure 2. The thickness of the nano-crystalline region decreases as the input $\mathrm{Al}: \mathrm{Si}$ ratio increases. Compositional analysis on the 2:1 and 3:1 samples, carried out in an STEM 
using a $40 \mathrm{~nm}$ electron probe, indicate a variation in the $\mathrm{Al}: \mathrm{Si}$ ratio across the thickness of the coatings. The $\mathrm{Al}: \mathrm{Si}$ ratio near the substrate is very low, a typical value is 0.326 and is presumed to be $\mathrm{SiO}_{2}$ at the substrate coating interface. The $\mathrm{Al}$ :Si ratio increases as the analysis proceeds through the nano-crystalline region. The coating begins to grow as (001) textured columnar mullite at the point where the $\mathrm{Al}: \mathrm{Si}$ ratio is between 2.93 and 3.77. This ratio overlaps with the known $\mathrm{Al}_{2} \mathrm{O}_{3}$ solid solubility of mullite (2.76-3.33). The $\mathrm{Al}$ : $\mathrm{Si}$ ratio continues to increase through the nano-crystalline region with maximum values approaching $7: 1$ at the top of the coating. The presence of a nano-crystalline region suggests that mullite is not forming directly as thermodynamics suggests but rather as $\mathrm{Al}_{2} \mathrm{O}_{3}$ and $\mathrm{SiO}_{2}$ separately. These molecules are absorbed on the surface of the silicon-based substrate with $\mathrm{SiO}_{2}$ initially preferred. Mullite nucleates when the $\mathrm{Al}: \mathrm{Si}$ ratio of the initial nano-crystalline coating reaches a critical value close to that of stoichiometric mullite.

Figure 3 illustrates the effect of growth rate upon the second method of controlling the input $\mathrm{Al}$ :Si ratio by maintaining the $P_{M C l x}$ at 0.53 torr and varying both $\mathrm{AlCl}_{3}$ and $\mathrm{SiCl}_{4}$ to achieve the desired ratio. The constant $P_{M C l x}$ value was 0.53 torr, the same value for the $2: 1$ coatings grown in Figure 1. Unlike in the varying $P_{M C l x}$ matrix the coatings grown at all mixed oxide compositions were uniform, fine-grained, and faceted mullite coatings. The degree of homogenous nucleation did not visually change throughout the mixed oxide range. Growth rates of coatings with an input $\mathrm{Al}: \mathrm{Si}$ ratio of 1:1, 2:1, and 4:1 did not vary significantly, however the growth rate of coatings grown at the stoichiometric mullite input ratio of 3:1 was significantly larger. Figure 4 indicates the $\mathrm{X}$-ray diffraction pattern of the mullite coating grown under the $\mathrm{Al}: \mathrm{Si}$ ratio of $3: 1$ with a $P_{M C l x}$ of 0.53 torr at $950^{\circ} \mathrm{C}$ and a total pressure of 75 torr 


\section{The Effects of Depletion}

Depletion through deposition and homogenous nucleation in a hot-walled reactor usually results in non-uniform coatings. Excessive homogenous nucleation results in powdery nonadherent coatings. Mullite deposition has the added complexity of multiple components. In an attempt to better understand the effects of depletion upon the uniformity of CVD mullite, a $10 \mathrm{~cm}$ long sample of $\mathrm{Si}_{3} \mathrm{~N}_{4}$ (Norton NT154) was placed parallel to input gas flow, as illustrated in Figure 5. The coated sample was sectioned and analyzed. There is a temperature gradient along the length of the sample with deposition at the bottom of the sample occurring at $930^{\circ}$ and the deposition at the top was $980^{\circ} \mathrm{C}$. Such a gradient is common in industrial CVD depositions to minimize the effects of depletion. Increased temperature is required to maintain a constant growth rate with increasingly depleted reactants. A constant growth rate was maintained along the entire length of the sample. SEM micrographs reveal that the coating becomes increasingly faceted from the bottom to the top. This is due to the increasing Al:Si ratio evident in the EDS quantitative analysis performed on each section

\section{The Effects of Post-Deposition Thermal Treatment}

Post-deposition heat treatments were conducted on $\mathrm{SiC}$ coated samples with coatings grown by varying $P_{M C l x}$ to achieve different $\mathrm{Al}$ :Si input ratios. Studies were conducted on mullite coatings grown at $\mathrm{Al}: \mathrm{Si}$ input ratios of $1: 1,2: 1,3: 1$, and $4: 1$, as well as $\mathrm{SiO}_{2}$. Separate coating sets were thermally treated in a vacuum tight chamber at atmospheric pressure in a flowing Ar environment at $1000^{\circ} \mathrm{C}$ for 100 hours, $1200^{\circ} \mathrm{C}$ for 100 hours, and $1350^{\circ} \mathrm{C}$ for 4 hours. The 
structures of mullite coatings on $\mathrm{SiC}$ grown at an input $\mathrm{Al}$ :Si ratio of $2: 1$ and heat treated under these conditions are shown in Figure 6. As the temperature of the annealing treatment increased the surface structure became increasingly featureless. X-ray diffraction of the coatings after heat treatment indicated that the only crystalline phases present were mullite and $\mathrm{SiC}$.

Figure 7 illustrates the surface structure of coatings produced with different input $\mathrm{Al}: \mathrm{Si}$ ratios by varying the partial pressure of metallic chlorides $\left(P_{M C l x}\right)$ after annealing at $1350^{\circ} \mathrm{C}$ for 4 hours. The coating grown with an input $\mathrm{Al}: \mathrm{Si}$ ratio of $2: 1$ is relatively featureless as compared to the coating grown with an input ratio of $4: 1$. The coatings grown with a larger $\mathrm{Al}: \mathrm{Si}$ input ratio maintained their surface structure better than the coatings grown with a lesser input $\mathrm{Al}: \mathrm{Si}$ input ratio. The surface structure of mullite coatings can be controlled during thermal treatments without any apparent adverse effects upon the integrity of the coating.

Grain growth did occur in the mullite coating as indicated in Figure 8 which compares the same coating before and after annealing at $1350^{\circ} \mathrm{C}$. Grain growth is particularly evident in the resolution of the (120),(210) peak doublet post-anneal. Grain growth most likely occurred through the conversion of columnar mullite grains into a coarse grained and textured mullite coating.

Uncoated and amorphous $\mathrm{SiO}_{2}$ coated $\mathrm{SiC}$ were subjected to elevated temperatures for comparative purposes. The X-ray diffraction patterns of Figures 9 and 10 indicate that both the native and deposited amorphous $\mathrm{SiO}_{2}$ crystallized at elevated temperatures. The $\mathrm{SiO}_{2}$ peak is evident in both the uncoated and initially amorphous $\mathrm{SiO}_{2}$ coated $\mathrm{SiC}$ at $22^{\circ}(2 \theta)$. An $\mathrm{SiO}_{2}$ 
crystalline phase is not evident in mullite coated samples that have been heat treated to $1000^{\circ} \mathrm{C}$, $1200^{\circ} \mathrm{C}$, or $1350^{\circ} \mathrm{C}$

Corrosive Environment Studies

Preliminary experimentation has begun to determine the degree of protection provided by mullite coatings on silicon-based ceramics in corrosive environments. Different corrosive environments may require mullite coatings with slightly different properties. This degree of control may be achieved with CVD mullite coatings.

\section{Oxidation Environment}

CVD mullite coated $\mathrm{SiC}$ was tested in an $\mathrm{O}_{2}$ rich environment at $1000^{\circ} \mathrm{C}$ for 100 hours [25]. As shown in Figure 11 an extremely low weight gain is observed past 30 hours of exposure. The extremely low weight change (little formation of oxide) is shown as the weight change versus square root of time(assuming parabolic oxide growth kinetics) for times greater than 30 hours. At this point, there is no statistical difference in the growth kinetics between mullite coated with an input Al:Si ratio of 2:1 $\left(P_{M C l x}=0.53\right.$ torr), 3:1 $\left(P_{M C l x}\right.$ of 0.53 torr $)$, and the slow diffusion rate of $\mathrm{O}_{2}$ through the protective $\mathrm{SiO}_{2}$ layer that forms on $\mathrm{SiC}$. 
$\mathrm{Na}_{2} \mathrm{SO}_{4}, \mathrm{O}_{2}$ Environment

CVD mullite coated $\mathrm{Si}_{3} \mathrm{~N}_{4}$ was subjected to a corrosive environment containing $\mathrm{Na}_{2} \mathrm{SO}_{4}$ and $\mathrm{O}_{2}$ at $1000^{\circ} \mathrm{C}$ for 100 hours [26]. The specimens were typically loaded with about $5 \mathrm{mg} / \mathrm{cm}^{2}$ of $\mathrm{Na}_{2} \mathrm{SO}_{4}$ and exposed to a flowing oxygen environment in a quartz tube heated to $1000^{\circ} \mathrm{C}$. The use of an oxygen environment results in a basic molten salt (i.e., high $\mathrm{Na}_{2} \mathrm{O}$ activity), thus facilitating the corrosive reaction of $\mathrm{Na}_{2} \mathrm{O}$ with native $\mathrm{SiO}_{2}$ seen on silicon based substrates according to the reaction:

$$
\begin{aligned}
& \mathrm{Na}_{2} \mathrm{SO}_{4}(\mathrm{l}) \rightarrow \mathrm{Na}_{2} \mathrm{O}(\mathrm{s})+\mathrm{SO}_{3}(\mathrm{~g}) \\
& \mathrm{Na}_{2} \mathrm{O}(\mathrm{s})+x \mathrm{SiO}_{2}(\mathrm{~s}) \rightarrow \mathrm{Na}_{2} \mathrm{O} \bullet x\left(\mathrm{SiO}_{2}\right)(\mathrm{l})
\end{aligned}
$$

The results of uncoated $\mathrm{Si}_{3} \mathrm{~N}_{4}$ and mullite coated $\mathrm{Si}_{3} \mathrm{~N}_{4}$ after exposure are shown in Figure 12. The presence of a Na-containing glassy phase is observed to a depth of $\approx 20 \mu \mathrm{m}$ below the initial substrate surface in the uncoated sample. Yttrium (used as a sintering aid in $\mathrm{Si}_{3} \mathrm{~N}_{4}$ ) migrated through the grain boundaries of the substrate to the substrate surface, resulting in the formation of a yttrium depleted zone of $\approx 10 \mu \mathrm{m}$. The mullite coated sample was relatively unaffected by the corrosive environment. It was found from TEM study that the remainder of the coating as well as the underlying $\mathrm{Si}_{3} \mathrm{~N}_{4}$ substrate were not affected either microstructurally or compositionally by the corrosion exposure. 


\section{Coal Slag}

With the desire to tailor CVD mullite coatings on ceramic heat exchangers in coal-fired systems for power production, CVD mullite coated $\mathrm{SiC}$ samples were exposed to corrosive coal slag at $1260^{\circ} \mathrm{C}$ for 300 hours [27]. Chemical composition of the coal slag is given in Table I. Corrosive coal slag will form extreme porosity and dramatic pit formation in unprotected SiC. After 300 hours of exposure all mullite coatings (Al:Si input ratios 2:1, 3:1, 4:1 achieved through varying $P_{M C l x}$ ) exhibited excellent protection. Generally, mullite grown with a lower input $\mathrm{Al}: \mathrm{Si}$ ratio exhibited a more corrosion resistant surface as shown in Table II. This trend agrees with the as deposited SEM analysis of mullite coatings in which an input $\mathrm{Al}$ :Si ratio of $2: 1\left(P_{M C l x} 0.53\right.$ torr) produced a more uniform coating than an input $\mathrm{Al}$ :Si ratio of $4: 1$ ( $P_{M C l x} 0.93$ torr).

\section{CONCLUSIONS}

Through the use of thermodynamic and kinetic analysis crystalline mullite coatings have been deposited via chemical vapor deposition upon silicon based materials such as $\mathrm{SiC}$ and $\mathrm{Si}_{3} \mathrm{~N}_{4}$. Altering process parameters such as deposition temperature and reactant partial pressure has resulted in mullite coatings with varied physical and chemical properties such as crystal structure, surface morphology, and chemical composition. Preliminary results have indicated that mullite coatings form an effective barrier to corrosion in high temperature corrosive environments including $\mathrm{Na}_{2} \mathrm{SO}_{4}-\mathrm{O}_{2}$, oxidation, and jet burner exhaust. 


\section{ACKNOWLEDGMENTS}

Research sponsored by the U.S. Department of Energy, Assistant Secretary for Energy Efficiency and Renewable Energy, Office of Transportation Technologies, as part of the Ceramic Technology Project of the Propulsion System Materials Program, and Fossil Energy AR\&TD Materials Program under contract numbers DE-AC05-840R21400 and SC-19X-SS110C with Martin Marietta Energy Systems, Inc. The authors would like to acknowledge Dr. Woo Lee, Dr. Tom Strangman, and Dr. Peter Tortorelli for corrosion testing, Ping Hou for TEM analysis, Dr. S. Basu for invaluable discussions, and Dave Stinton for his guidance. 


\section{REFERENCES}

1. W.J. Lackey, D.P. Stinton, et.al., Advanced Ceram. Mat., 2 [1], 24-30, (1987)

2. N.S. Jacobson, J.Am. Ceram. Soc., 76 [1], 3-28, (1993)

3. W.J. Lackey, D.P. Stinton, et.al., ORNL/TM-8959 (1984)

4. I.A. Aksay, D.M.Dabbs, M. Sarikaya, J. Am. Ceram. Soc., 74 [10] 2343-58 (1991)

5. P.F.Becher, J. Am. Ceram. Soc., 74 [2] 255-69 (1991)

6. S.Somiya, Y. Hirata, Am. Ceram. Soc. Bull., 70 [10] 1624-32 (1991)

7. R.D. Nixon, S. Chevacharoenkul, R.F. Davis, and T.N. Tiegs, pp. 579-603 in Ceramic Transactions, Vol. 6, Mullite and Mullite Matrix Composites, Edited by S. Somiya, R.F. Davis, and J.A. Pask, American Ceramic Society, Westerville, OH, 1990

8. D.G.W. Smith and J.D.C. McConnel, Mineral. Mag., 35 [274] 810-14 (1966)

9. T. Epicier, J. Am. Ceram. Soc., 74 [10] 2359-66 (1991)

10. C.W. Burnham, Carnegie Institute Washington Year Book, 63, 227-228, (1964)

11. J. Schienle, and J. Smyth, Final Report, ORNL/Sub/84-47992/1 (1987)

12. K. Okada, N. Otsuka, pp.425-34 in Ceramic Transactions, Vol. 6, Mullite and Mullite Matrix Composites, Edited by S. Somiya, R.F. Davis, and J.A. Pask, American Ceramic Society, Westerville, OH, 1990

13. O.R. Monteiro, Zhi Wang, Ian G. Brown, J. Mat. Res., To be Published

14. K.N. Lee, N.S. Jacobson, R.A. Miller, MRS Bulletin 19 [10], 35-38, (1994)

15. R.P. Mulpuri, and V.K. Sarin, $19^{\text {th }}$ Annual Cocoa Beach Conference and Exposition on Engineering Ceramics, Cocoa Beach, FL, The American Ceramic Society, Westerville, OH, (Jan. 1995)

16. R.P. Mulpuri, and V.K. Sarin, J. Mater. Res., 11 (6), 1315-24, (1996)

17. Ph, Wong, M. Robinson, J.Am Ceram. Soc., 53, 617-21, (1970)

18. W.Steinmaier, J.Bloem, J. Electro. Soc.,111 (2), 206-209, (1964) 
19. G.L. Tingey, J. Phy. Chem., 70 (5), 1406-1412, (1966)

20. W.Steinmaier, J.Bloem, J. Electro. Soc.,111 (2), 206-209, (1964)

21. S.W. Choi, C. Kim, et.al., pp.233-41 in the proceedings of the IX International Conference on CVD (CVD-IX), as part of the Electrochemical Society Meeting held in Cincinnati, OH, May 7-10, 1984, ed. McD. Robinson, The Electrochemical Society Inc., Pennington, NJ, 1984

22. H. Altena, K. Stjernberg, B. Lux, pp. 381-90 in the proceedings of the V European Conference on CVD (Euro-CVD-V), held in Uppsala, Sweden, June 17-20, 1985, ed. J. O. Carlsson, Uppsala University, Department of Chemistry, Uppsala, Sweden

23. V.K. Sarin and R.P. Mulpuri, U.S. Pat. Pending

24. D.Doppalaupudi, et.al., pp. 664-70 in the proceedings of the XIII Annual CVD Conference, as part of the Electrochemical Society Meeting held in Los Angeles, CA, May 5-10, 1996, ed. T.M.Besmann, The Electrochemical Society Inc. Pennington, NJ, 1996

25. Testing performed by Dr. Tortorelli of Oak Ridge National Laboratory, Oak Ridge, TN

26. W.Y. Lee, K.L. More,Y.W. Bae, J. Am. Ceram. Soc., 79 (9), 2489, (1996)

27 Testing performed by Dr. K. Breder of Oak Ridge National Laboratory, Oak Ridge, TN. For further test information see: K. Breder, et.al., "Strength Measurements of Monolithic SiC and $\mathrm{Al}_{2} \mathrm{O}_{3} / \mathrm{SiC}$ Composites after Exposure to Coal Slag," J. Am. Ceram. Soc., 78 (10), 2837-40, (1995) 
Partial Pressure of Metallic Chlorides ( $\left.P_{M C L}\right)$, (torr)

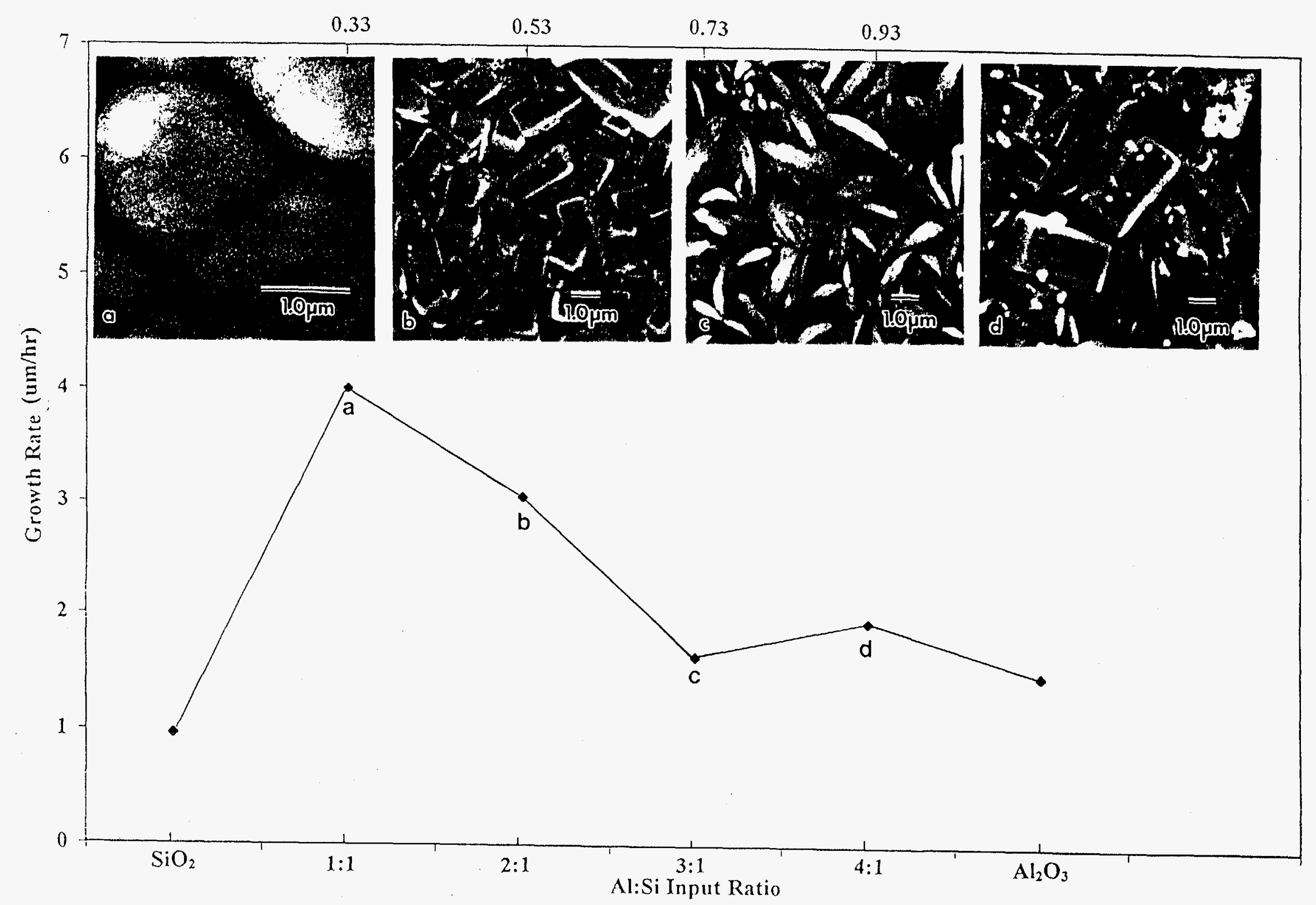

Figure 1: Growth rate of mullite vs. reactant $\mathrm{Al}$ :Si ratio and variable metallic chloride partial pressure 


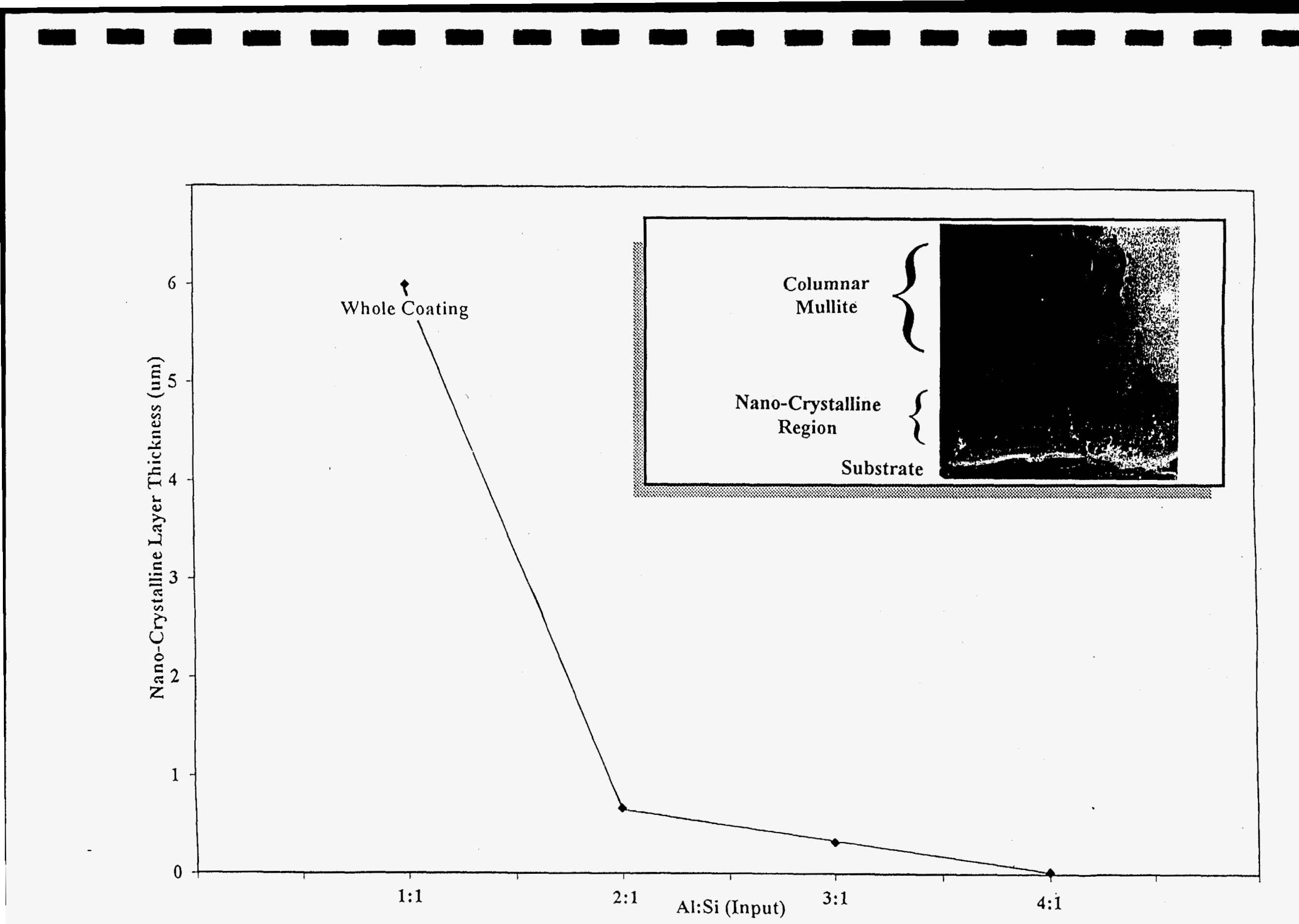

Figure 2: Nano-crystalline layer thickness of mullite coatings vs. reactant Al:Si ratio. Inset is the typical microstructural evolution of mullite coatings on silicon-based materials. 


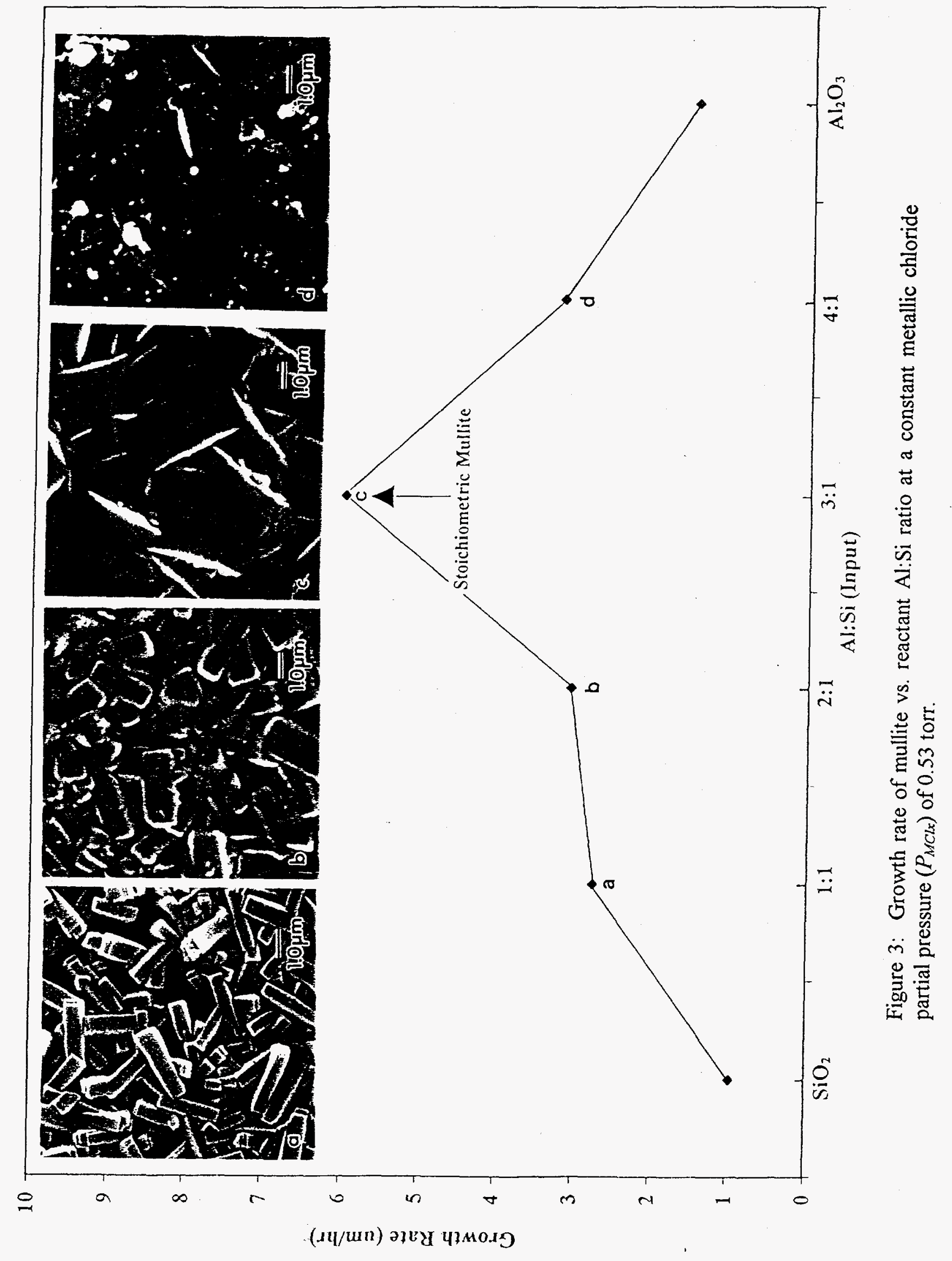




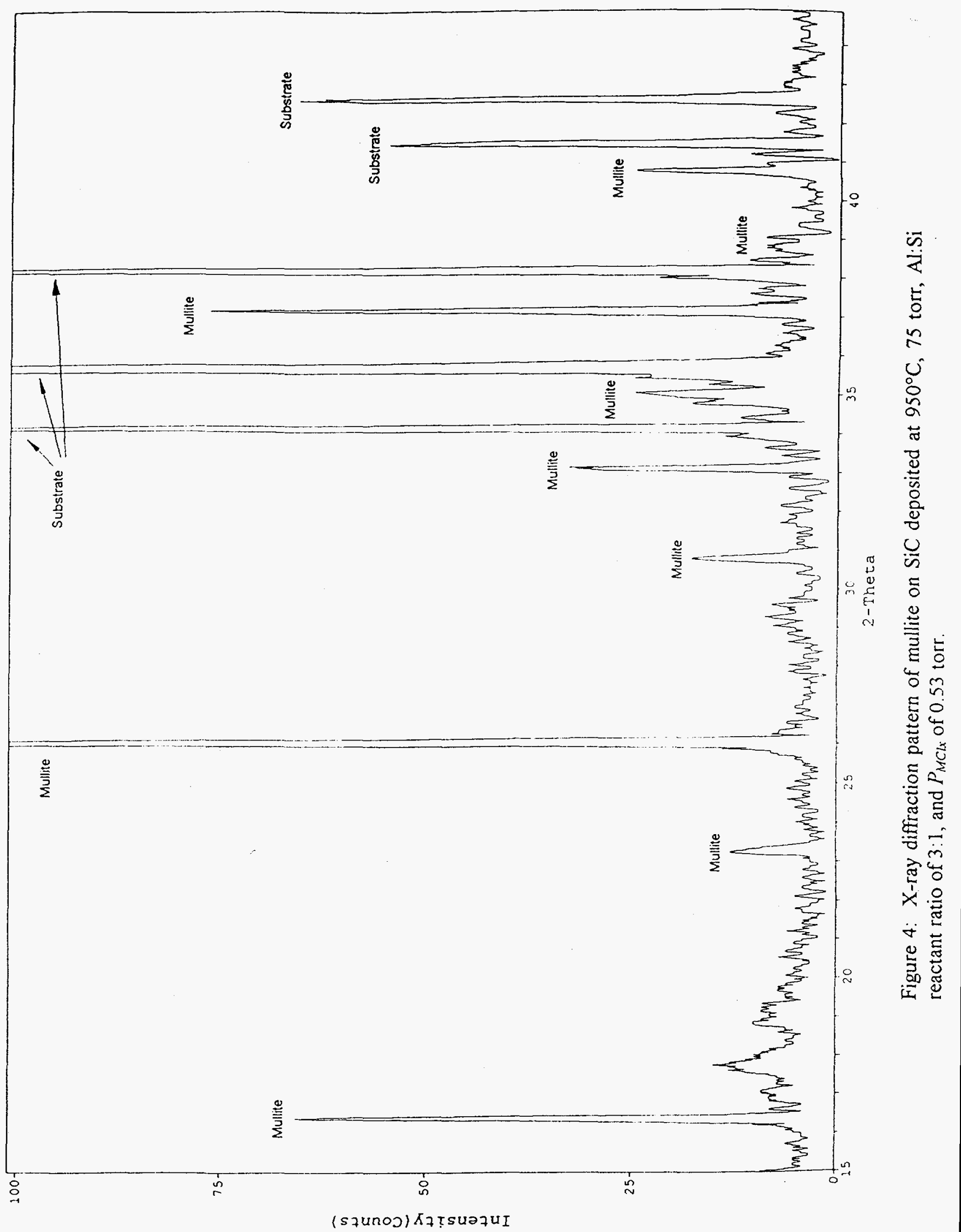




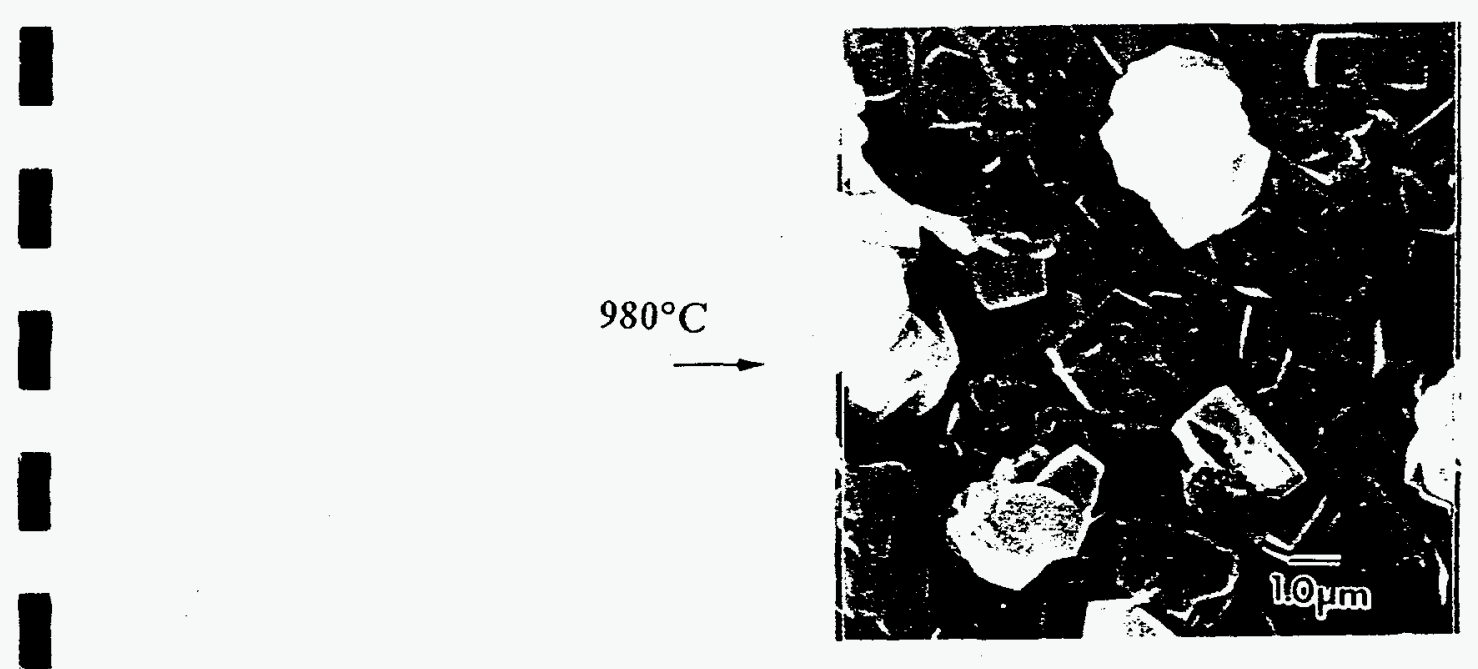

EDS Surface Analysis Al:Si of Mullite Surface

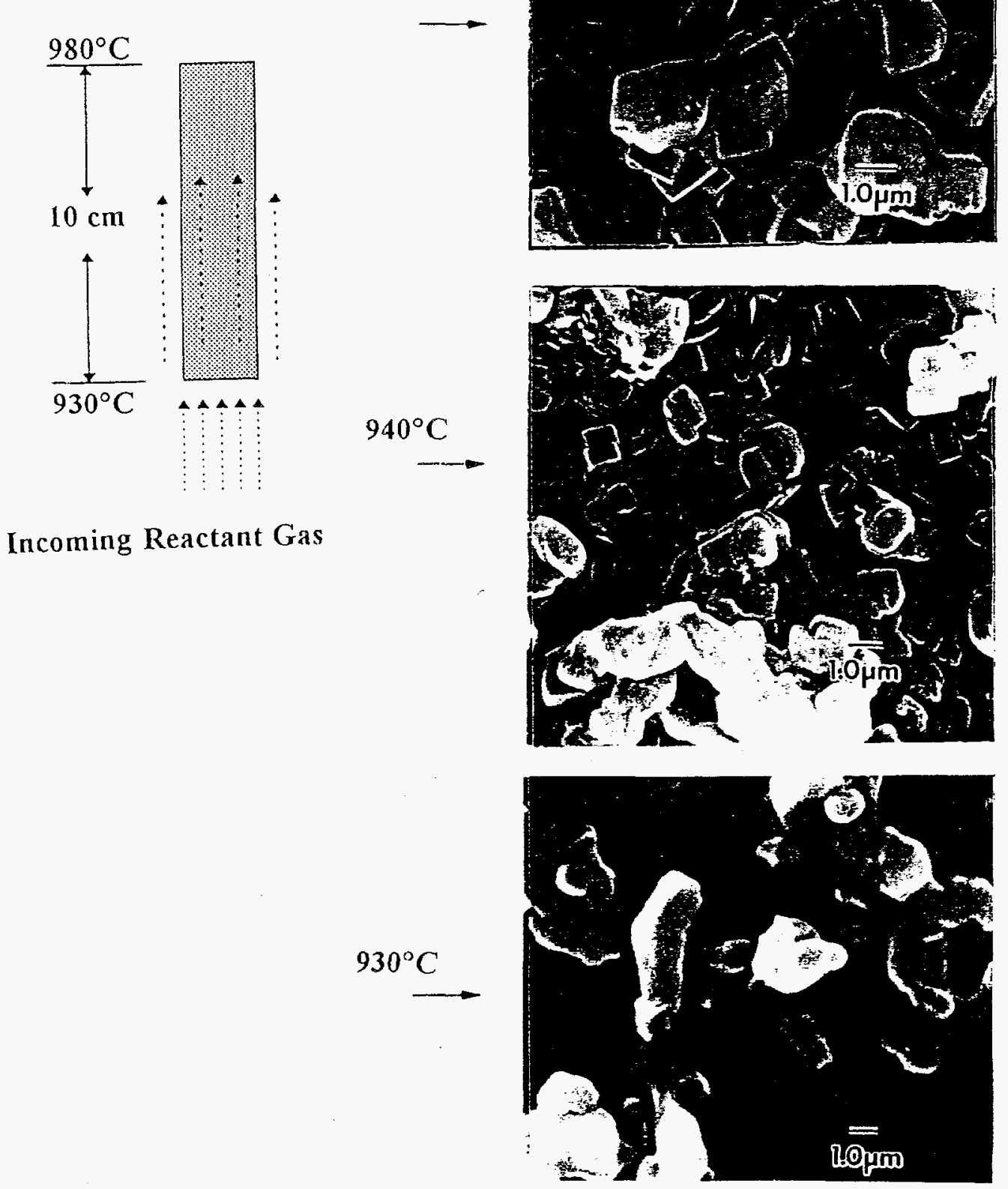

$4: 1$

$3: 1$

$1.4: 1$

Regions of $\mathrm{SiO}_{2}$

Figure 5: Difference in surface structure and chemical composition of mullite grown on $\mathrm{Si}_{3} \mathrm{~N}_{4}$ where the sample is placed parallel to reactant gas flow. 


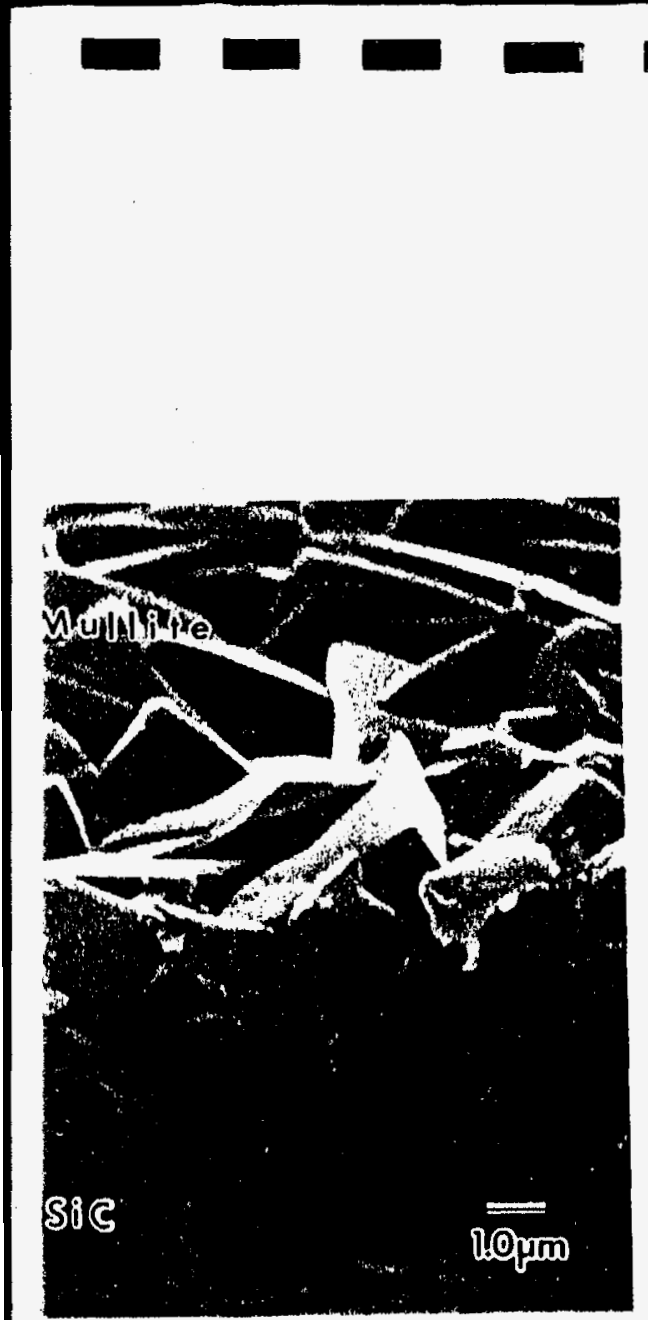

As Grown

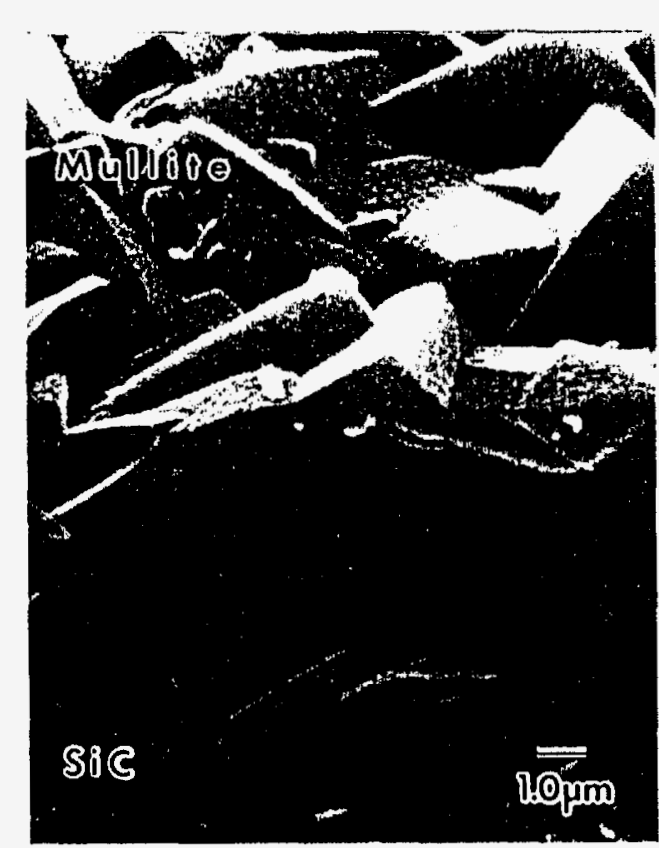

$1000^{\circ} \mathrm{C}$

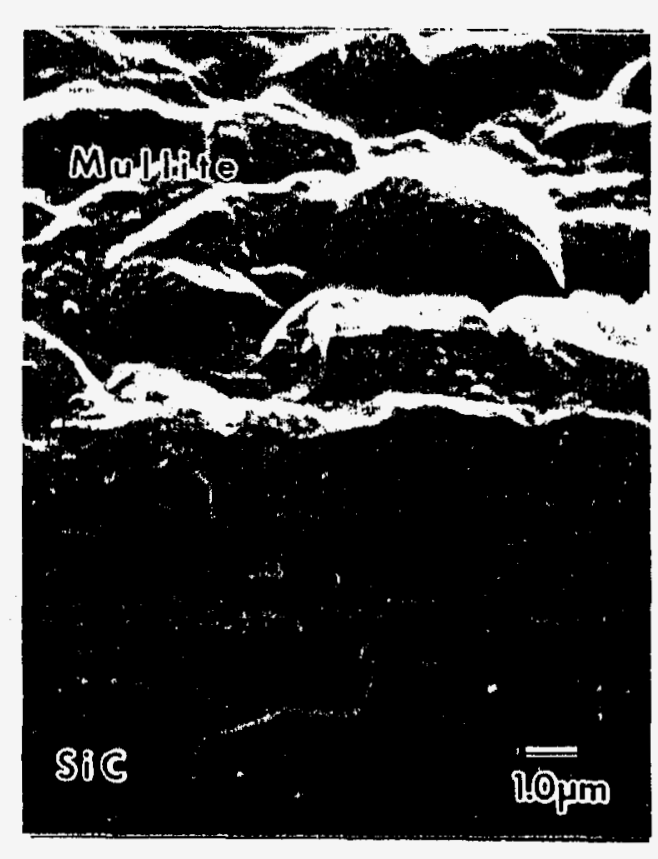

$1200^{\circ} \mathrm{C}$

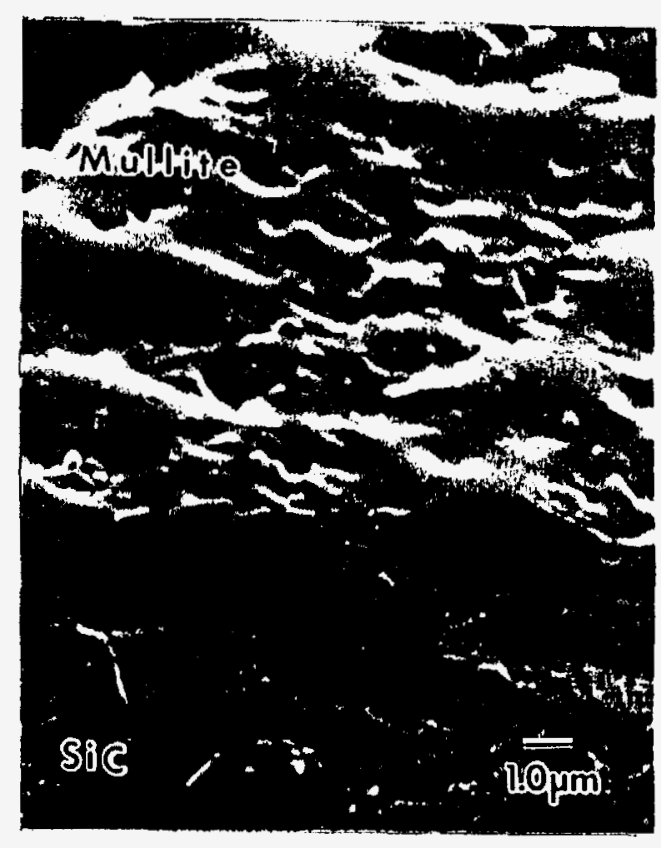

$1350^{\circ} \mathrm{C}$

Figure 6: Surface structure of mullite as deposited, annealed in $\operatorname{Ar} @ 1000^{\circ} \mathrm{C}$ for 100 hours, annealed @ $1200^{\circ} \mathrm{C}$ for 100 hours, and $1350^{\circ} \mathrm{C}$ for 4 hours. 

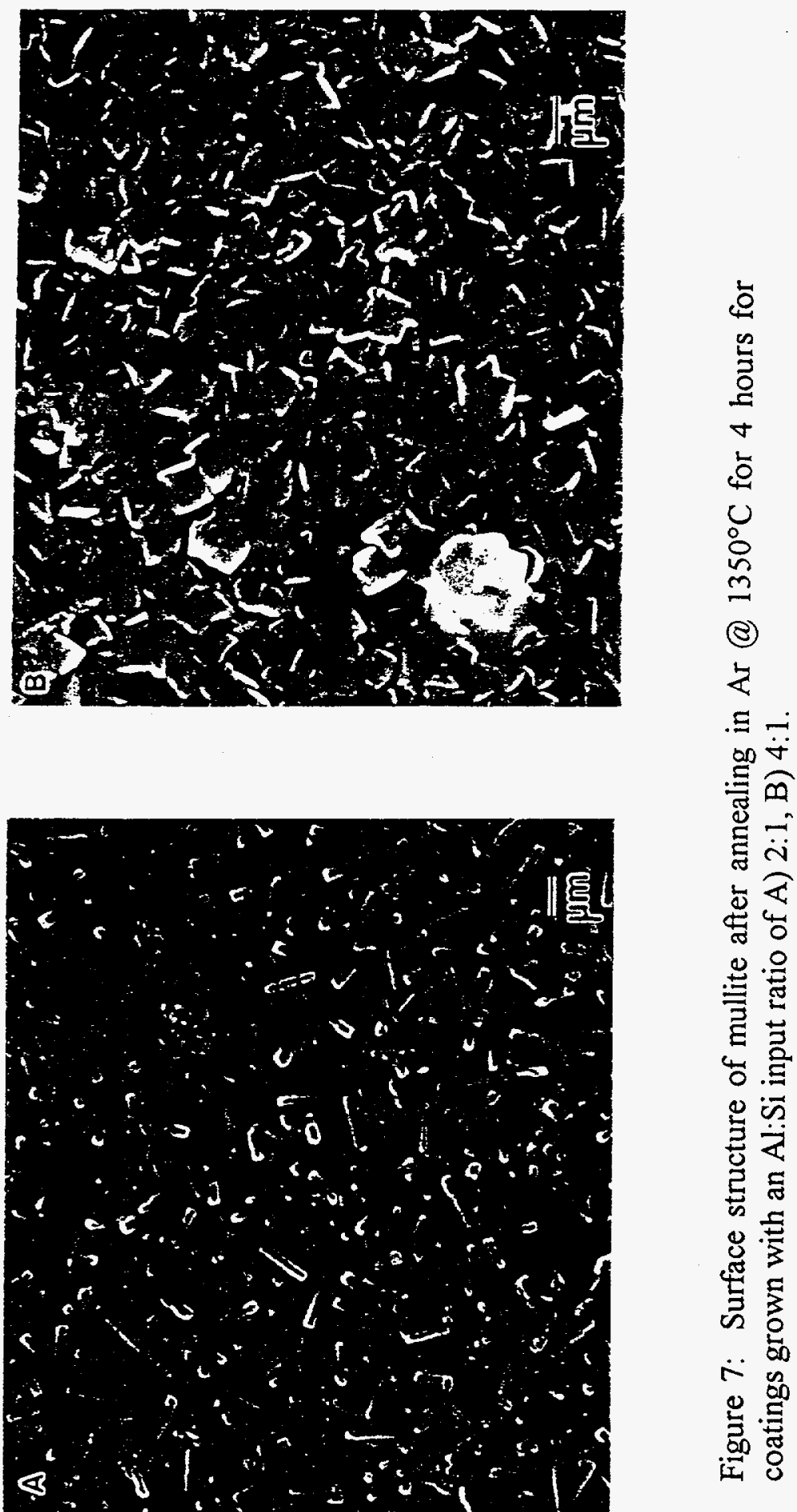

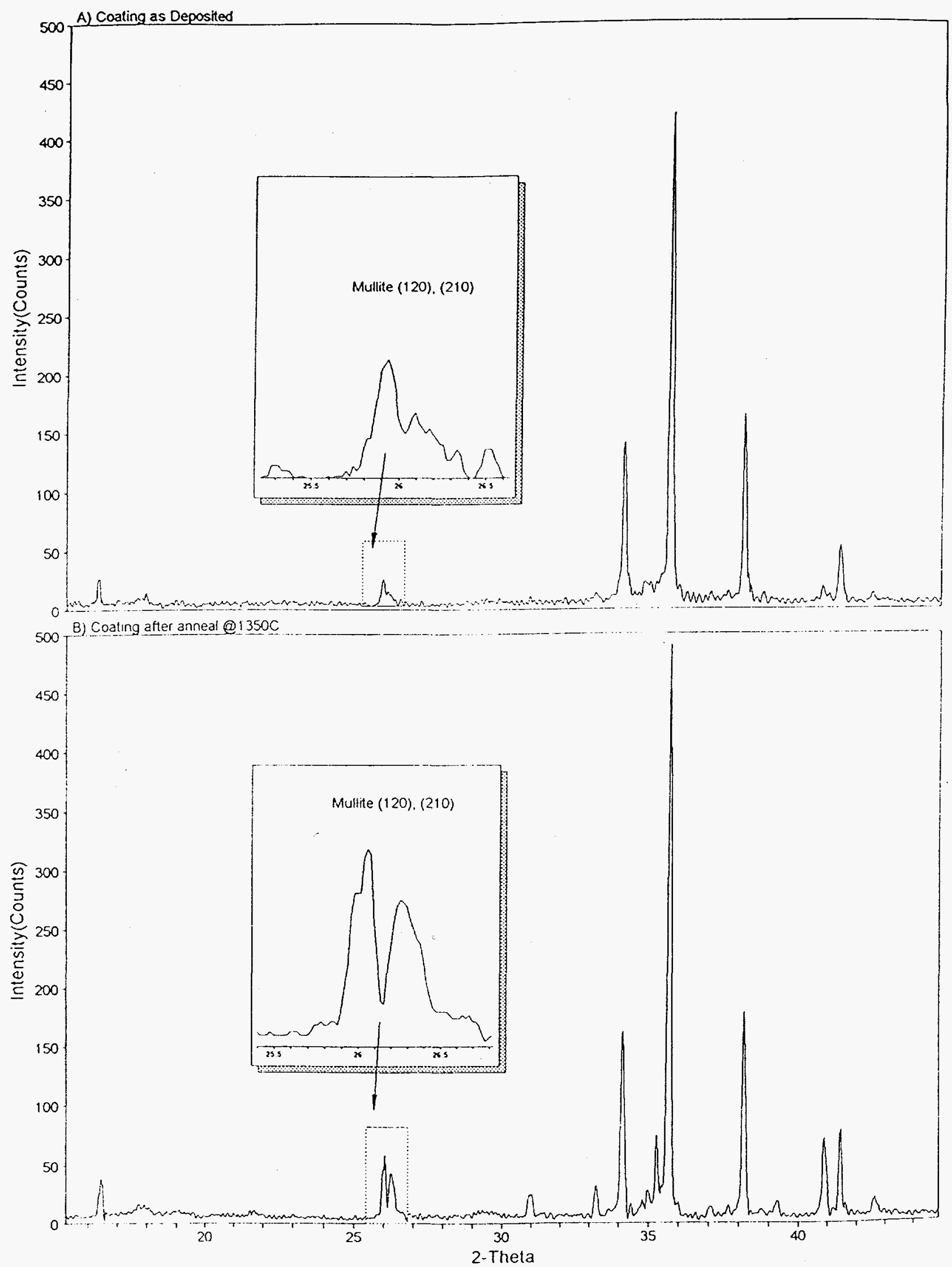

Figure 8: X-ray diffraction pattern for a mullite coating A) As Deposited, B) After annealing in $\mathrm{Ar} @ 1350^{\circ} \mathrm{C}$ for 4 hours. 

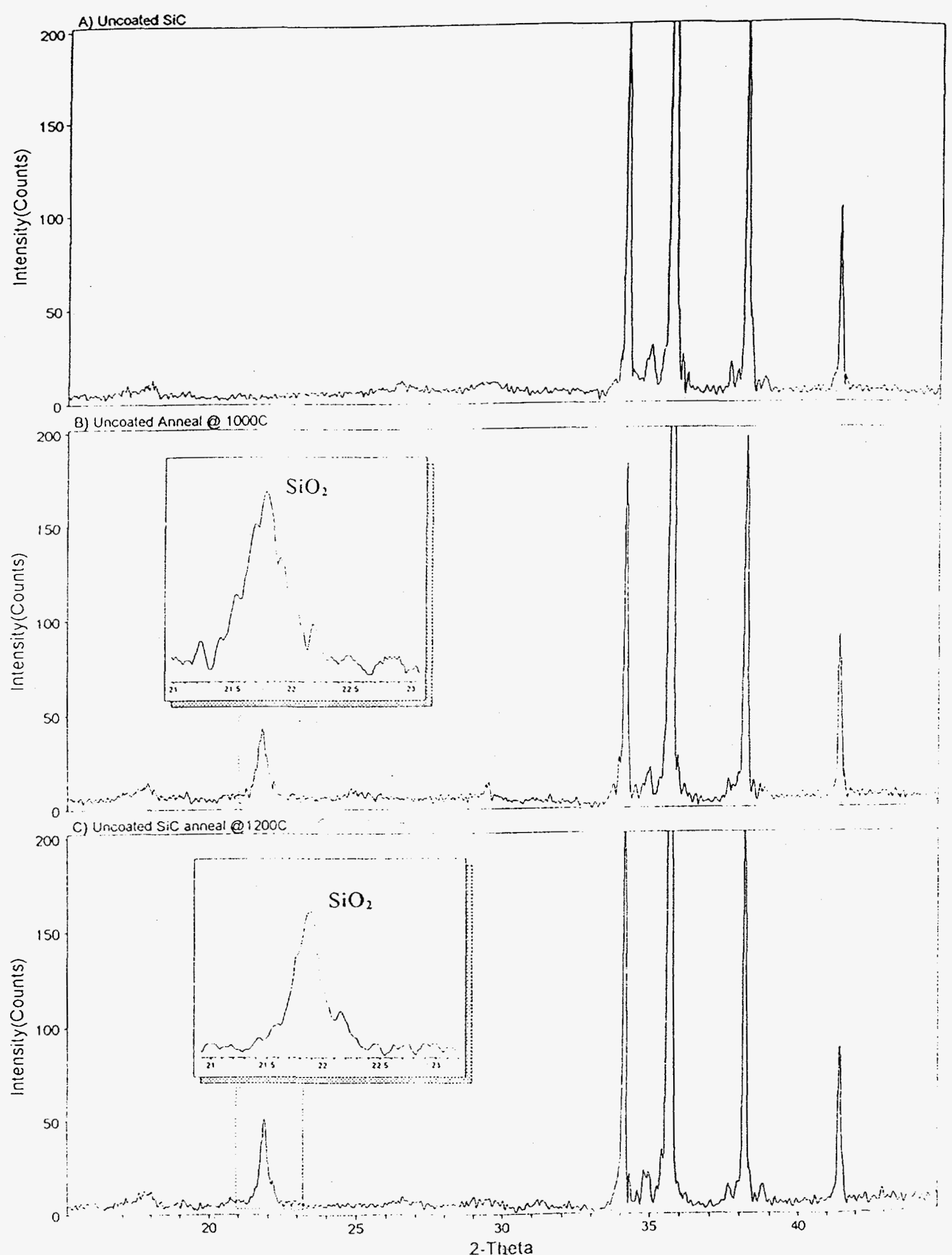

Figure 9: X-ray diffraction patterns for uncoated $\mathrm{SiC}, \mathrm{A})$ As deposited, B) Heat treated in $\mathrm{Ar} @ 1000^{\circ} \mathrm{C}$ for 100 hours, C) @ $1200^{\circ} \mathrm{C}$ for 100 hours. 

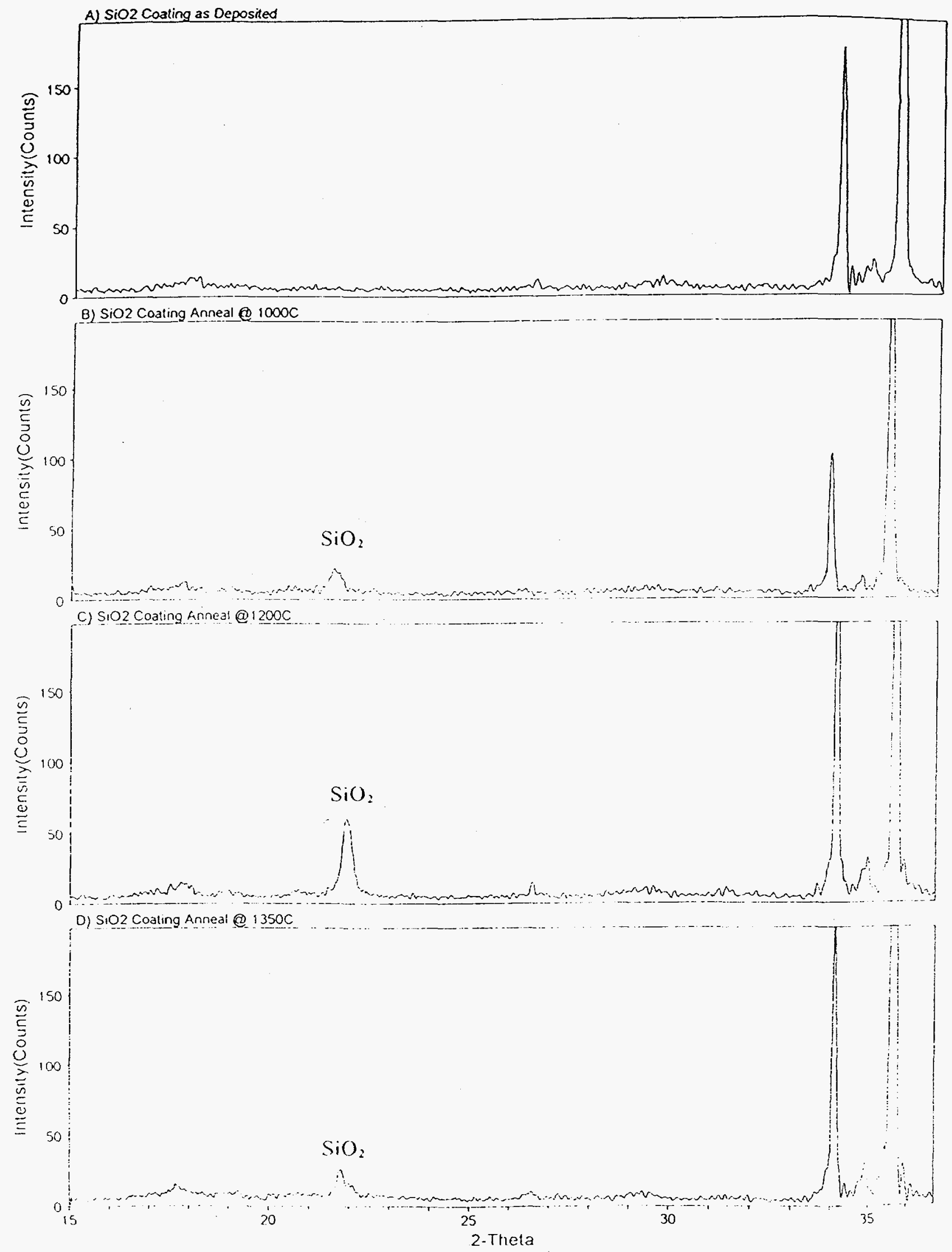

Figure 10:X-ray diffraction patterns for $\mathrm{SiO}_{2}$ coated $\left.\mathrm{SiC}, \mathrm{A}\right)$ As deposited, B) Heat treated in Ar@1000 $\mathrm{C}$ for 100 hours, C) @ $1200^{\circ} \mathrm{C}$ for 100 hours, D) @ $1350^{\circ} \mathrm{C}$ for 4 


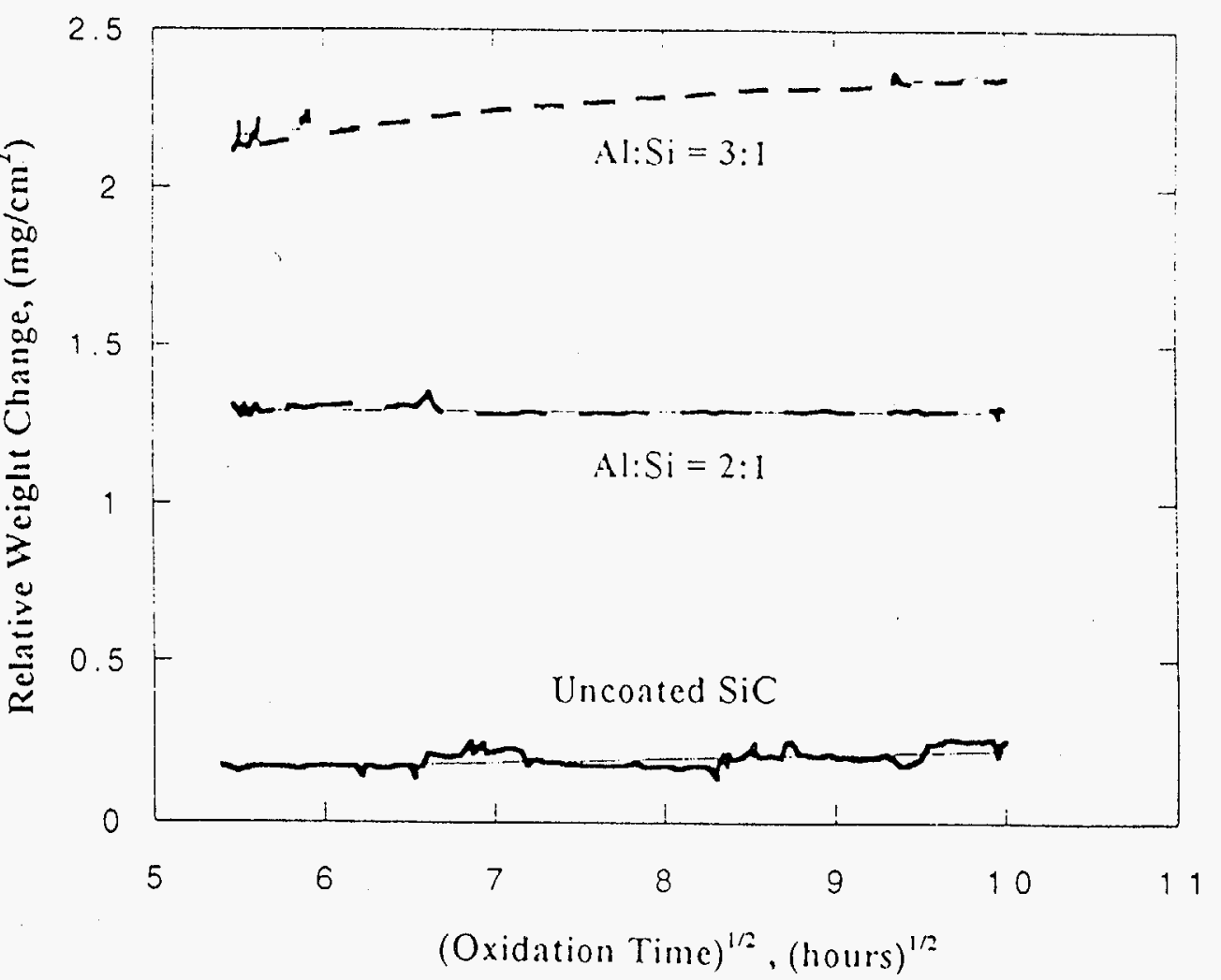

Figure 11: Relative weight change of uncoated $\mathrm{SiC}$ and mullite coatings grown at reactant $\mathrm{Al}: \mathrm{Si}$ ratios of $2: 1$ and $3: 1$ on $\mathrm{SiC}$ vs. (oxidation time) ${ }^{1 / 2}$ in a flowing air environment @ $1000^{\circ} \mathrm{C}$. [Tortorelli Ref. 25] 


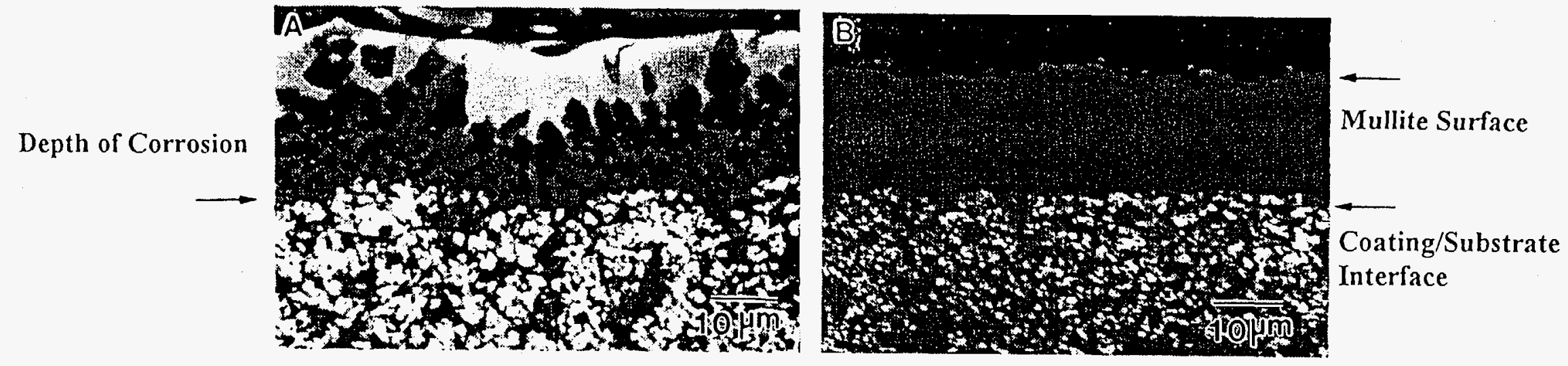

Figure 12: Comparison between, A) Uncoated $\mathrm{Si}_{3} \mathrm{~N}_{4}$ and B) Mullite coated $\mathrm{Si}_{3} \mathrm{~N}_{4}$ subjected to a $\mathrm{Na}_{2} \mathrm{SO}_{4}-\mathrm{O}_{2}$ environment at $1000^{\circ} \mathrm{C}$. White areas on the material surface are the result of corrosion.[Woo Lee Ref. 26] 


\begin{tabular}{|c|c|}
\hline Oxide & wt \% \\
\hline $\mathrm{SiO}_{2}$ & 53.4 \\
$\mathrm{Al}_{2} \mathrm{O}_{3}$ & 18.6 \\
$\mathrm{Fe}_{2} \mathrm{O}_{3}$ & 17.6 \\
$\mathrm{TiO}_{2}$ & 0.7 \\
$\mathrm{P}_{2} \mathrm{O}_{5}$ & 0.0 \\
$\mathrm{CaO}$ & 7.1 \\
$\mathrm{MgO}$ & 0.9 \\
$\mathrm{Na}_{2} \mathrm{O}$ & 0.0 \\
$\mathrm{~K}_{2} \mathrm{O}$ & 1.7 \\
$\mathrm{SO}_{3}$ & 0.0 \\
\hline
\end{tabular}

Table I: Chemical composition of coal slag which resulted from coal burned at Illinois Power Company Baldwin Plant. Commonly referred to as Baldwin coal slag. [ Breder, Ref. 27]

\begin{tabular}{|c|c|}
\hline Al:Si (Input Ratio) & Observations \\
\hline $2: 1$ & Very Clean, no pitting observed \\
\hline $3: 1$ & Clean, possible beginning of pit formation \\
\hline $4: 1$ & Clean, possible beginning of pit formation \\
\hline Uncoated SiC & Corrosion beginning \\
\hline
\end{tabular}

Table II: Observations of mullite grown with different input $\mathrm{Al}$ :Si ratios on $\mathrm{SiC}$ and exposed to Baldwin coal slag for 300 hours at $1260^{\circ} \mathrm{C}$. [Breder, Ref. 27] 
3M COMPANY

Ceramic Materials Department

201-4N-01 3M Center,

St. Paul, MN 55144

M. A. Leitheiser

AIR PRODUCTS AND CHEMICALS

P.O. Box 538

Allentown, PA 18105

S. W. Dean

ALLISON GAS TURBINE DIVISION

P.O. Box 420

Indianapolis, IN 46206-0420

P. Khandelwal (Speed Code W-5)

R. A. Wenglarz (Speed Code W-16)

AMA RESEARCH \& DEVELOPMENT CENTER 5950 Mclntyre Street

Golden, CO 80403

T. B. Cox

ARGONNE NATIONAL LABORATORY

9700 S. Cass Avenue

Argonne, IL 60439

W. A. Ellingson

J. P. Singh

BABCOCK \& WILCOX

Domestic Fossil Operations

20 South Van Buren Avenue

Barberton, $\mathrm{OH} 44023$

M. Gold

\section{BRITISH COAL CORPORATION}

Coal Technology Development Division

Stoke Orchard, Cheltenham

Glocestershire, England GL52 4ZG

J. Oakey

CANADA CENTER FOR MINERAL \& ENERGY

TECHNOLOGY

568 Booth Street

Ottawa, Ontario

Canada K1A OG1

R. Winston Revic

Mahi Sahoo
DOE

DOE OAK RIDGE OPERATIONS

P.O.Box 2001

Oak Ridge, TN 37831

Assistant Manager for

Energy Research and Development

DOE

DOE OAK RIDGE OPERATIONS

P. O. Box 2008

Building 4500N, MS 6269

Oak Ridge, TN 37831

M. H. Rawlins

DOE

OFFICE OF BASIC ENERGY SCIENCES

Materials Sciences Division

ER-131

19901 Germantown Road

Germantown, MD 20874-1290

H. M. Kerch

DOE

IDAHO OPERATIONS OFFICE

P. O. Box 1625

Idaho Falls, ID 83415

J. B. Malmo

DOE

MORGANTOWN ENERGY TECHNOLOGY CENTER

P.O. Box 880

Morgantown, WW 26505

R. C. Bedick

D. C. Cicero

F. W. Crouse, Jr.

R. A. Dennis

N. T. Holcombe

W. J. Huber

T. J. McMahon

J. E. Notestein

DOE

OFFICE OF FOSSIL ENERGY

FE-72

19901 Germantown Road

Germantown, MD 20874-1290

F. M. Glaser 


\section{DOE}

OFFICE OF VEHICLE AND ENERGY R\&D

CE-151 Forrestal Building

Washington, DC 20585

R. B. Schulz

DOE

PITTSBURGH ENERGY TECHNOLOGY

CENTER

P.O. Box 10940

Pittsburgh, PA 15236

A. L. Baldwin

G. V. McGurl

L. A. Ruth

T. M. Torkos

DOW CORNING CORPORATION

3901 S. Saginaw Road

Midland, MI 48686-0995

H. Atwell

EC TECHNOLOGIES

3614 Highpoint Drive

San Antonio, TX 78217

D. J. Kenton

ELECTRIC POWER RESEARCH INSTITUTE

P.O. Box 10412

3412 Hillview Avenue

Palo Alto, CA 94303

W. T. Bakker

J. Stringer

EUROPEAN COMMUNITIES JOINT RESEARCH

CENTRE

Petten Establishment

P.O. Box 2

1755 ZG Petten

The Netherlands

M. Van de Voorde

GEORGIA INSTITUTE OF TECHNOLOGY

Materials Science \& Engineering (0245)

Bunger-Henry Building, Room 276

Atlanta, GA 30332-0245

T. L. Starr
IDAHO NATIONAL ENGINEERING LABORATORY

P. O. Box 1625

Idaho Falls, ID 83415

B. H. Rabin

LAWRENCE LIVERMORE NATIONAL LABORATORY P.O. BoX 808, L-325

Livermore, CA 94550

W. A. Steele

NATIONAL MATERIALS ADVISORY BOARD

National Research Council

2101 Constitution Avenue

Washington, DC 20418

K. M. Zwilsky

OAK RIDGE NATIONAL LABORATORY

P.O. Box 2008

Oak Ridge, TN 37831

P. T. Carlson

F. D. Johnson (5 copies)

R. R. Judkins

D. P. Stinton

M. R. Upton

OFFICE OF NAVAL RESEARCH

Code 431, 800 N. Quincy Street

Arlington, VA 22217

S. G. Fishman

SHELL. DEVELOPMENT COMPANY

WTC R-1371

P.O. Box 1380

Houston, TX 77251-1380

W. C. Fort

TENNESSEE VALLEY AUTHORITY

Energy Demonstration \& Technology

MR2N58A

Chattanooga, TN 37402-2801

C. M. Huang

THE JOHNS HOPKINS UNIVERSITY

Materials Science \& Engineering

Maryland Hall

Baltimore, MD 21218

R. E. Green, Jr. 
THE MATERIALS PROPERTIES COUNCIL, INC. United Engineering Center

345 E. Forty-Seventh Street

New York, NY 10017

M. Prager

\section{THE NORTON COMPANY}

High Performance Ceramics Division

Goddard Road

Northborough, MA 01532-1545

N. Corbin

THE TORRINGTON COMPANY

Advanced Technology Center

59 Field St.

Torrington, CT 06790

W. J. Chmura

UNION CARBIDE CORPORATION

Linde Division

P.O. Box 44

175 East Park Drive

Tonawanda, NY 14151-0044

Harry Cheung

UNITED TECHNOLOGIES RESEARCH CENTER

MS 24, Silver Lane

East Hartford, CT 06108

K. M. Prewo

UNIVERSITY OF TENNESSEE

Dept of Materials Science and Engineering

Knoxville, TN 37996-2200

Peter Liaw

UNIVERSITY OF WASHINGTON

Department of Materials Science and

Engineering

101 Wilson, FB-10

Seattle, WA 98195

T. G. Stoebe

VIRGINIA POLYTECHNIC INSTITUTE \& STATE UNIVERSITY

Department of Materials Engineering

Blackburg, VA 24601

K. L. Reifsnider
WESTERN RESEARCH INSTITUTE

365 N. 9th Street

P.O. Box 3395

University Station

Laramie, WY 82071

V. K. Sethi

WESTINGHOUSE ELECTRIC CORPORATION

Research and Development Center

1310 Beulah Road

Pittsburgh, PA 15235

S. C. Singhal 